\title{
The Curious Case of Early Muslim Hair Dyeing
}

\author{
Ahmed El Shamsy
}

Toward the end of his life, Ahmad b. Hanbal (d. 241/855), the hadith expert, jurist, and paragon of Sunni piety, received a sick visit from a group of people, among them an older man with dyed hair. Upon seeing the man, Ahmad declared, "How it delights me to see an old man with dyed hair!" Then he mentioned someone who was not present and asked, "Why does he not dye [his hair]?" The visitors answered, "He is ashamed." Ahmad exclaimed in exasperation, "God be praised; [it is] a tradition from the Prophet!" On another occasion Ahmad catalogued the hair-dyeing practices of hadith scholars whom he personally knew: of the sixty-nine scholars he mentioned, forty-eight dyed their hair and twenty-one did not. ${ }^{2}$ Ahmad b. Hanbal was by no means the only hadith scholar with a keen interest in hair dyeing: 'Abd al-Razzāq alȘan'ānī (d. 211/827) transmitted numerous hadith reports from his teacher Ma'mar b. Rāshid (d. 153/770) on the topic, and a generation after Ahmad, Muhammad b. Jarīr al-Ṭabarī (d. 310/923) dedicated more than sixty pages of his Tahdhīb al-äthār to citing and discussing reports relating to male hair dyeing (khid̄āb, ikhtid̄a $b$, șibāgh). ${ }^{3}$ (By "hair dyeing" we should understand, throughout this paper, the dyeing of grey or white hairs both on the head and in the beard.)

This paper argues that the considerable volume of discussion in early hadith literature on the issue of men dyeing their hair can grant us significant insight into the logic of early Muslim identity and norm formation. The first to address

1 Abū Bakr al-Khallāl, al-Wuqūfwa-l-tarajjul min al-Jāmi li-masāìl Aḥmad b. Hanbal, ed. Sayyid Kasrawī Ḥasan (Beirut: Dār al-Kutub al-'Tlmiyya, 1994), 131.

2 Aḥmad b. Hanbal, Masāil al-Imām Aḥmad b. Hanbal, riwāya Ibn Abì al-Faụl Șāliḥ, ed. Faḍl al-Raḥmān Dīn Muhạmmad, 3 vols. (Delhi: al-Dār al-'Tlmiyya, 1988), 2:374-381 (man kāna yakhdab min al-muhaddithin).

3 Ma'mar b. Rāshid, al-Jāmi', vols. 11 and 12 of 'Abd al-Razzāq al-Ṣanānī's al-Mușannaf, ed. Habīb al-Raḥmān al-A'ẓamī (Simlak: al-Majlis al-'Ilmī, 1970-1972), 11:153-156; Muḥammad b. Jarīr alṬabarī, Tahdhīb al-āthār: al-Juz' al-mafqūd, ed. 'Alī Riḍā (Damascus: Dār al-Ma’mūn, 1995), 415-517. See also Ibn Abī Shayba, al-Muṣannaf, ed. Kamāl al-Ḥūt, 7 vols. (Riyadh: Maktabat alRushd, 1409/1988 or 1989), 5:182-184; Abū Yūsuf, al-Āthār, ed. Abū al-Wafā' al-Afghānī (Hyderabad: Dār Ihyāà al-Ma‘ārif al-'Uthmāniyya, 1355/1936), 234 (no. 1037). 
this topic in Western scholarship was Gautier H.A. Juynboll in a 1986 article. ${ }^{4}$ Three decades later, it is time to reconsider the issue, for two main reasons: first, we now have access to a much greater range of sources, which enable us to fill in gaps where Juynboll had to speculate; and second, the scope of our imagination regarding what hadith are and what one can do with them has expanded dramatically, beyond the Schachtian theorisation that still very much underpins Juynboll's article.

I begin by briefly summarising the main findings of Juynboll's article. I then offer a different interpretation of the material he presented and support this interpretation by introducing previously unknown sources from outside of the Islamic tradition. After establishing the form and meaning of hair dyeing among early Muslims, I conclude by drawing out the significance of this haircare phenomenon for our understanding of the relationship between hadith and law in the early period.

In his hair-dyeing article, Juynboll sought to explain a cluster of hadith reports in which Muhammad enjoins his followers to dye their hair, recommends ways of doing it, and distinguishes the practice from the contrary customs of the Jews and Christians. The article takes a Schachtian view of the origins of these hadith reports, arguing that after the conquests the Arabs came into contact with a new cultural practice of men dyeing their hair; they adopted it and subsequently appropriated it by inventing hadith that encouraged the practice. In support, Juynboll points out that hair dyeing was a common practice in Egypt, the Levant, and the Fertile Crescent well before the advent of Islam, whereas Muslim sources and pre-Islamic poetry suggest that it was not well known or practiced among the Arabs before Islam. He then turns to the hadith reports in question, seeking to understand the various colours and dyeing agents described in them. This task is more difficult than one might think. The most commonly recommended dyeing agent is a combination of henna and katam, as in the hadith "The best way of changing this white is with henna and katam." ${ }^{5}$ While the henna plant (hinna $\overline{\text {, }}$ Lawsonia inermis) and the vivid red colour it produces are widely known, katam is more obscure; Juynboll tentatively identifies it as a plant with the English common name Dyer's woad (Isatis tinctoria) ${ }^{6}$ He quotes Abū Hanīfa al-Dīnawarīs (d. 282/895)

4 Gautier H.A. Juynboll, "Dyeing the Hair and Beard in Early Islam: A Ḥadīth-analytical Study," Arabica 33, no. 1 (1986): 49-75.

5 Aḥmad b. Ḥanbal, Musnad al-imām Aḥmad b. Hanbal, eds. Shu'ayb al-Arna’ūt, 'Ādil Murshid et al., 45 vols. (Beirut: Mu'assasat al-Risāla, 1993-2001), no. 21307 .

6 Juynboll, "Dyeing the Hair and Beard," 5o. It appears that the Arabic term wasma, also dis- 
observation that katam darkens the colour of henna and concludes that the combination produced a dark colour. This conclusion appears to contradict another hadith, which claims that the combination of henna and katam produces the colour șufra. Instead of accepting the word's common lexical meaning of "yellow" or "orange," Juynboll excavates another possible meaning of sufra, a de facto opposite (didd), as "black." A further hadith, according to which Muhammad recommended that Abū Bakr's father dye his hair red and forbade him to dye it black, is dismissed by Juynboll as an exceptional measure that Muhammad took to make fun of a man who had only recently converted to Islam.

Juynboll then identifies a second group of hadith reports, which explicitly forbid dyeing one's hair black. He argues that the pro-dyeing hadith scholars, who were seeking to legitimise a practice that Arabs had adopted from their non-Arab subjects, were from Kufa, whereas the minority anti-dyeing hadith scholars, who were hostile to this innovation, were from Basra. ${ }^{7}$ Juynboll also examines the isnāds of the pro-dyeing hadith but reaches no firm conclusions beyond pointing out that a number of their common links are scholars who died in the early second Islamic century. He concludes his article by speculating that the pro-dyeing hadith were most likely invented by hadith scholars who were also herb-sellers and who sought to use the fabricated hadith to promote their business, which included the sale of hair-dyeing agents.

The key feature of Juynboll's article is that it takes as its starting point the hypothesis that the hadith on hair dyeing are later fabrications to justify a cultural adoption by Muslims from their non-Muslim subject populations, and it then interprets the evidence in light of this assumption. Juynboll takes it for granted that the purpose of male hair dyeing was cosmetic-to hide the effects of aging - and thus would have required the use of naturalcoloured (dark brown or black) dye. However, this approach requires selective and often contrived use of the evidence. It forces Juynboll to excavate a marginal meaning for the word șufra instead of accepting the more intuitive common one; to construe Muhammad's comment to Abū Bakr's father as an act of ridicule; and to ignore a significant amount of relevant evidence that points to a preference for artificial reddish hues. This evidence includes a hadith in which Muhammad tells believers with greying beards, "Colour

cussed by Juynboll, refers to indigo leaf: Ibn Qayyim al-Jawziyya, al-Tibb al-nabawī (Beirut: Dār al-Hilāl, 1983), 278 (the work was extracted from Ibn al-Qayyim's Zād al-ma`ād).

7 Juynboll, "Dyeing the Hair and Beard," 63. 
[them] red and yellow" (hammirū wa-șaffirū); $;$ the preference expressed by the second-century Medinan scholar Mālik b. Anas (d. 179/796) for colours other than black (which Juynboll actually mentions in another context); ${ }^{9}$ the description of Abū Bakr's beard as being "like a blazing fire from henna and katam"; 10 a hadith according to which some of the companions used the yellowish substances turmeric (wars) and saffron (zafarān) to dye their hair and beards; ${ }^{11}$ and the depiction of the prominent second-generation Muslim scholar Ibn Shihāb al-Zuhrī (d. 124/741) as "red of hair and beard, with a tinge of katam."12 In addition, the great hadith commentators, such as Ibn 'Abd alBarr in the fifth/eleventh century and al-'Aynī in the ninth/fifteenth century, clearly interpreted the colours in question as other than black: they concluded that according to the overwhelming majority of hadith scholars up to their own times, men should dye their grey hair red or yellow (al-hamra wa-l-sufra), but not black (sawād). ${ }^{13}$ This interpretation is also supported by evidence from poetry. Abū Tammām's (ca. 188-231/8o4-845) great poem on the conquest of Amorium in 223/838 describes the city's slain Byzantine defenders thus:

How many a heroic horseman lay between her walls

His forelocks reddened by hot flowing blood!

His hair hennaed by the way (sunna) of the sword—blood his henna Not by the way (sunna) of religion and Islam. ${ }^{14}$

In other words, Abū Tammām compares the Byzantine warriors, whose hair has been reddened by their own blood, with the Muslims, whose hair is red from henna in accordance with the prophetic example. Taken together, these sources overwhelmingly indicate that the hadith in question refer to dyeing the hair

8 Ahmad b. Hanbal, Musnad Ahmad, no. 22283.

9 Juynboll, "Dyeing the Hair and Beard," 58.

10 al-Ṭabarī, Tahdhīb al-äthār, 460.

11 Ahmad b. Hanbal, Musnad Ahmad, no. 15882.

12 Shams al-Dīn al-Dhahabī, Tārīkh al-islām, ed. Bashshār 'Awwād Ma' rūf, 15 vols. (Beirut: Dār al-Gharb al-Islāmī, 2003), 3:499.

13 Ibn 'Abd al-Barr, al-Tamhìd li-mā fì al-Muwațta' min al-ma'ānì wa-l-asānīd, eds. Mușțafā al-'Alawī and Muhammad al-Bakrī, 24 vols. (Rabat: Wizārat al-Awqāf, 1974-1992), 21:8384; Badr al-Dīn al-'Aynī, 'Umdat al-qārī, 25 vols. (Cairo: al-Mațba'a al-Munīriyya, 1929), 22:51.

14 Bi-sunnat al-sayfi wa-l-ḥinnā̉i min damihi ... lā sunnat al-dīni wa-l-islāmi mukhtadibi, in The Poetics of Islamic Legitimacy: Myth, Gender and Ceremony in the Classical Arabic Ode, trans. Suzanne Pinckney Stetkevych (Bloomington: Indiana University Press, 2002), 158. 
red, yellow, or similar colours that diverge from the Arabs' natural hair colour. By contrast, as Juynboll notes, the evidence on the pre-Islamic pre-conquest societies of the Middle East relates to the use of black (or, on occasion, blond) hair dye. ${ }^{15}$ The idea that these hadith reports were fabricated in order to Islamise an originally foreign practice thus seems untenable.

Furthermore, the practice of mixing henna and katam as a hair dye continues to this day in the Muslim world, and it has also gained a following in the Western world given the nonaggressive and even beneficial nature of this mix for hair. As a result, we know that katam is, pace Juynboll, a dye produced from Buxus dioica, ${ }^{16}$ a shrub related to the boxwood tree, and that combining it with henna is done both to lock the colour into the hair for a longer time and to tone down and darken the brightness of henna in order to produce a reddish-brown colour that is less garish than that given by henna alone but clearly not black, and in fact close to the effect yielded by turmeric and saffron. ${ }^{17}$

Thus, instead of two competing hadith traditions pro and contra dyeing, we are faced with a single tradition that discouraged men from dyeing their hair black and advocated dyeing it a reddish or reddish-brown colour. Juynboll in fact considers this possibility in his article but immediately dismisses it, asking: "What is the point in dyeing one's white hair yellow/orange, if one wants to conceal the "hateful white?"'18 That is a very good question, to which I now turn.

The first possible explanation is that male hair dyeing was a pre-Islamic Arab custom, possibly a ritualistic marking similar to tattoos. When these newly converted Arabs then encountered non-Arabs after the conquests, the pre-existing practice was justified in religious terms through hadith, in a manner similar to the justification of turbans as the crowns of the Arabs. ${ }^{19}$ Dyeing the hair with henna was almost certainly known in pre-Islamic Arabia, as Imru' al-Qays memorably compared the blood of a hunted gazelle to "henna juice upon an old man's combed and hoary head." 20

15 Juynboll, "Dyeing the Hair and Beard," 52.

16 On Buxus dioica, see the Jsтов Global Plants database at https://plants.jstor.org/compilat ion/Buxus.dioica, last accessed 10 December 2017.

17 There are extensive discussions on the use of henna and katam, including images of the effects of various combinations of them, in numerous internet forums; see, for example, http://forums.3roos.com/3roos439878/, last accessed 21 April 2016.

18 Juynboll, "Dyeing the Hair and Beard," $5^{2-53}$.

19 See, for example, Abū 'Abd Allāh al-Quḍā̄ì, Musnad al-Shihāab, ed. Ḥamdī al-Salafì, 2 vols. (Beirut: Mu’assasat al-Risāla, 1986), 1:75.

20 Translated by Suzanne Pinckney Stetkevych in The Mute Immortals Speak: Pre-Islamic Poetry and the Poetics of Ritual (Ithaca, NY: Cornell University Press, 1993), 255. 
The second possible explanation is that male hair dyeing was not undertaken for reasons of vanity - to conceal the "hateful white"-but rather for the purpose of differentiating its practitioners from other groups. This hypothesis is commensurable with the observation that hair dyeing in unnatural colours (specifically, the artificial reddish hues produced by agents such as henna) was known in pre-Islamic Arabia, but it differs from the first potential explanation in that the hadith on the topic would reflect not simply an act of religious rubber stamping, but rather a deeper religio-communal function served by the practice. This explanation also coincides with the explicit rationale given in several of the hadith reports in question, which urge Muslims to dye their hair in order to distinguish themselves from non-Muslims: "Change the white and do not imitate (lä tashabbahü) the Jews"; "Change the white and do not imitate the Jews or the Christians"; "The Jews and the Christians do not dye [their hair], so differentiate yourselves from them (fa-khälifühum)."21 Juynboll was familiar with these reports, but he did not assign them any value; for him, they were part of the false internal narrative of hadith. However, if Juynboll's own theory is implausible, as I have argued, it is worth reconsidering the hadith that recommend the dyeing of hair in unnatural colours as part of the la tashabbahü/khälifü genre of hadith, which prescribes certain practices for the express purpose of distinguishing Muslims from nonMuslims. These hadith, as Meir Jacob Kister has argued, "seem to belong to a very early phase of Islam, in which it was felt to be essential for the nascent Muslim community to establish distinctive features for its own religious rites and practices, so as to differentiate itself from all other religious communities." 22

This interpretation of the hair dyeing hadith gains support from two nonMuslim sources to which Juynboll did not have access but which provide a historical perspective on the Arabs' hair-dyeing practices. The first of these is a text known as the Arabic Apocryphal Gospel of John. ${ }^{23}$ This gospel appears

21 Aḥmad b. Hanbal, Musnad Aḥmad, nos. 1415, 7545, 7274.

22 Meir Jacob Kister, “'Do not assimilate yourselves ...': lā tashabbahū," Jerusalem Studies in Arabic and Islam 12 (1989): 340. Kister brought together and examined several of these reports (although nothing on hair dyeing), treating them as authentic without much examination. For a more extensive treatment of the discourse on Muslim/non-Muslim distinction, see Youshaa Patel, "Muslim Distinction: Imitation and the Anxiety of Jewish, Christian, and Other Influences" (PhD diss., Duke University, 2012).

23 For this text, I am indebted to the work of Cornelia Horn, especially a paper she gave at the 2012 meeting of the American Oriental Society in Boston on 17 March 2012, titled "Apocalyptic Ecclesiology in Response to Early Islam: The Evidence of the Arabic Apocryphal Gospel of John." See also Cornelia Horn, "Editing a Witness to Early Interactions 
to have been translated from Syriac into Arabic before or around the year $184 / 800,{ }^{24}$ and in the process of translation several elements were added to the text, including a prophecy of the Arab conquests. To summarise the prophecy, the text predicts the rise of a people who come from the desert; oppress Christians; hold theologically deviant views; flood the earth; capture the sacred temple (in Jerusalem); seek to abolish Christ's rules; enslave and kill Christians, considering it an act of worship; dye their beards with dried herbs; and conquer much of the known world. ${ }^{25}$ The prophecy's only specific information about the physical appearance of the Arabs concerns their dyed beards. ${ }^{26}$ While no colours are mentioned, it seems unlikely that the beards were dyed black, because that would hardly produce a noticeable feature. Also, black hair colour in antiquity was (and in places like Yemen is until today) mostly derived from ingredients such as walnut and gall and metals such as iron and lead, not from herbs. ${ }^{27}$ By contrast, both henna and katam are extracted from shrubby plants. This source thus indicates that the practice of dyeing the beard in reddish hues was widespread enough among the early Muslim Arabs to serve as the defining

between Christian Literature and the Qurān: status quaestionis and Relevance of the Arabic Apocryphal Gospel of John," Parole de l'Orient 37 (2012): 1-16; Horn, "Syriac and Arabic Perspectives on Structural and Motif Parallels Regarding Jesus' Childhood in Christian Apocrypha and Early Islamic Literature: The 'Book of Mary,' the Arabic Apocryphal Gospel of John and the Qur'ān," Apocrypha 19 (2008): 267-291.

24 Horn, "Syriac and Arabic Perspectives," 287.

25 The italics are mine. The relevant text reads:

$$
\begin{aligned}
& \text { ستأتي أمة يكون مخرجه من القفارترذل أمتي ويقول عن الله قولاً ما قاله } \\
& \text { غيرها من الأمم وتطمت الأرض وتطأ هيكل قدسي ويجتهدون في إبطال قوانيني يسبون أولاد } \\
& \text { شعبي من الاباء والأههات والبنين والبنات ويبيعونهم فيما بينهم وفي سائر البلدان ويقتلون من سبوه } \\
& \text { شيخاً ويخضبون أيديهم بدمائهم ويظنون أهم قد قربوا بذلك قرباناً لله ومن زي هذه الأمة أنهم } \\
& \text { يخضبوا (يخضبون) لحاهم بالحشيشة الطمة ويملكون أكثر البر والبحر }
\end{aligned}
$$

Iohannis evangelium apocryphum Arabice, ed. Giovanni Galbiati (Milan: Arnoldo Mondadori Editore, 1957), 111. I read the section on dyeing as bi-l-hashishat al-tumma. For the word țumma, see Ibn Durayd, Jamharat al-lugha, ed. Ramzī Munīr Ba lbakī, 3 vols. (Beirut: Dār al-'Ilm li-l-Malāyīn, 1987-1988), 1:151 (root t-m-m).

26 That the observation refers specifically to the Arabs' beards, not their heads, could be due to a practice of wearing head coverings.

27 Victoria Sherrow, For Appearance'Sake: The Historical Encyclopedia of Good Looks, Beauty, and Grooming (Phoenix: Oryx Press, 2001), 138; Hannelore Schönig, Schminken, Düfte und Räucherwerk der Jemenitinnen: Lexikon der Substanzen, Utensilien und Techniken (Beirut: Orient-Institut, 2002), 41-42. 
shibboleth of the conquering Arabs for the Christian writers of the apocryphal gospel. This clearly contradicts Juynboll's hypothesis of the adoption and promotion of a foreign, pre-conquest practice by an enterprising group of hadith scholars. Of course, the speculative dating of the gospel to the year $184 / 800$ means that its recording was not contemporary to the conquests, but I believe it nonetheless has value: first, because on other points relating to the conquests the account appears to preserve an authentic early memory, very different from second-century Abbasid conditions; and second, because the fact that hair dyeing appears to have been such a clearly differentiating feature makes it likely that the practice was both indigenous and widespread among the Arabs, rather than a later adoption or a minority practice limited to a few hadith scholars.

This conclusion is supported by a second Christian source, the history of Dionysius of Tell-Mahre, which was composed in the third/ninth century but drew on earlier Christian chroniclers. At one point the history describes a group of early Muslims, saying that their beards have been dyed with henna, "as it is the custom of the Arabs to do."28

Finally, in an account of the Islamic conquest of Iberia, hair dyeing appears again as a distinguishing characteristic of the conquerors: when the people of the city of Merida met the Arab commander Mūsā b. Nuṣayr (19-97/640-716) on several occasions over the course of the year $94 / 713$ to discuss the surrender of the city, they found him grey-haired on their first encounter, red-haired at their next meeting, and eventually sporting black hair, and they concluded that he must possess supernatural powers. ${ }^{29}$ The account comes from Ibn Ḥayyān (d. 469/1076), who used older sources in his work. ${ }^{30} \mathrm{I}$ do not mean to argue that this report is necessarily historically accurate, but it provides another example of the recurring image of hair dyeing as a distinguishing mark of the early Arab conquerors-an image used by both Muslims and non-Muslims, both in the West and in the central lands of the Muslim empire.

This is not the only way in which hair was used as an identity marker in early Islam. Another well-attested hadith advises Muslim men to "trim [their]

28 Robert Hoyland, Seeing Islam as Others Saw It (Princeton, NJ: Darwin Press, 1997), 669, n. 231. On Dionysius, see 416-419. It is possible that these are not two independent sources but that either one draws on the other or they share a common source.

29 Muhammad b. 'Idhārī, Kitāb al-Bayān al-mughrib fí akhbār al-Andalus wa-l-Maghrib, eds. George Colin, Evariste Lévi-Provençal, and Iḥsān 'Abbās, 4 vols. (Beirut: Dār al-Thaqāa, 1967), 2:15; Aḥmad b. Muḥammad al-Maqqarī, Naf̣̣ al-ṭīb, ed. Iṇsān 'Abbās, 8 vols. (Beirut: Dār Șādir, 1968), 1:27o. I am grateful to Maribel Fierro for these references.

3o Ambrosio Huici Miranda, "Ibn Ḥayyān," Encyclopaedia of Islam, and ed. (Leiden: Brill, 1971), 3:789-79o. 
moustaches and let [their] beards grow." ${ }^{31}$ In some recensions of this report, the advice is preceded by the statement "Differentiate yourself from the polytheists," which adds to the command an identity-forming motivation that relates to the Muslims' situation in Mecca, where they were surrounded by the majority pagan Arab society, before their exodus in 622 to Medina, where they came into contact with Jews. Another early report, by Muhammad's cousin Ibn 'Abbās, claims that Muhammad wore his hair open, both to distinguish himself from the pagan Arabs who braided their hair and to follow the example of the Jews and the Christians, because he preferred to adopt the ways of the People of the Book in matters regarding which he had received no specific divine guidance. ${ }^{32}$

This report, of course, seems to contradict the hair-dyeing hadith and their rationale of differentiation, and Muslim historians also saw the apparent contradiction. The Andalusian exegete al-Qurțubī (d. 671/1272) proposed the following explanation:

[Muhammad] preferred to adopt their ways in his early days in Medina, when he prayed in the same direction as they did [i.e., toward Jerusalem] and sought to draw close to them. But when this proved of no use with them and misfortune befell them, he ordered [the Muslims] to differentiate themselves from them in many areas. The reason for the preference for the ways of the People of the Book, rather than those of the polytheists, is that the former adhere to the remains of the laws of the prophets, whereas the latter are pagans with nothing to draw on except what they found their forefathers doing. ${ }^{33}$

This explanation identifies two phases in Muhammad's mission. In the first phase, Muhammad sought primarily to distance himself and his community from the pagan Arabs while embracing the outward appearance associated with Jews and Christians, thus signalling his closeness to them and seeking to entice them to join him. In the second phase, once these hopes of rapprochement had been dashed, he then adopted a policy of symbolic distinction from the People of the Book, while retaining a fundamental doctrinal affinity with their teaching. This theory of distinct phases of assimilation and differentiation gains support from the Qurān, which also depicts two historical stages

31 Ahmad b. Ḥanbal, Musnad Aḥmad, no. 4654 and footnote.

32 Muḥammad b. 'İsā al-Tirmidhī, al-Shamāil al-muḥammadiyya, ed. Muḥammad 'Awwāma (n.p.: n.p., 2001), 112.

33 Quoted in Ibrāhīm al-Bājūrī, al-Mawāhib al-laduniyya, included in al-Tirmidhī, al-Shamā̉il al-muhammadiyya, 112. 
in Muhammad's relations with Jews and Christians: the first features optimism about finding common cause, whereas the second is characterised by disillusionment. ${ }^{34}$

Let me summarise my argument so far. First, male hair dyeing appears to be an early practice among Muslims; even Juynboll, generally a sceptic, affirmed its presence around the year 100 of the Hijra in both Syria and Iraq, and I would assume it to be even earlier than that. Second, the kind of hair dyeing advocated in these hadith reports involved unnatural colours; in other words, it was intended to make the fact that the hair was dyed immediately visible. And third, both the hadith themselves and the other sources indicate that the dyeing functioned as an effective communal boundary marker between Muslims and the other religious groups in their environment.

What made hair dyeing in particular suited to this purpose? The repeated references in the hadith to differentiating Muslims from Jews appear to offer a promising avenue of enquiry. In his 2006 book After Hardship Cometh Ease, Ze'ev Maghen speculates in a footnote that the hair-dyeing hadith could constitute the earliest source for the prohibition in Jewish law against men dyeing their hair to hide its greying, a position that is clearly articulated by the time of Maimonides's Mishneh Torah in the seventh/thirteenth century. ${ }^{35}$ This prohibition is based on a biblical injunction for men not to imitate women who seek to disguise their grey hairs (Deuteronomy 22:5). Significantly, Maimonides situates this discussion in the section on foreign worship (Avodah Zarah), that is, among rules concerned with distinguishing Jews from nonJews. ${ }^{36}$ The apparent overlap between the Muslim and Jewish discourses on the subject is strengthened by the fact that a related rule in Jewish law-namely, the prohibition on plucking out grey hairs, which is already Talmudic-also appears in the hadith corpus (where it is termed natfal-shayb), and it is often found either together with or immediately adjacent to the hadith on hair dyeing. ${ }^{37}$

34 Marco Schöller, "Opposition to Muhammad," Encyclopaedia of the Qur'ān, ed. Jane Dammen McAuliffe, accessed 3 February 2018, https://referenceworks.brillonline.com/entries/ encyclopaedia-of-the-quran/opposition-to-muhammad-EQCOM_oor39?s.num=o\&s.f.s2 _parent=s.f.book.encyclopaedia-of-the-quran\&s.q=Opposition+to+Mu\%E1\%B8\%A5am mad.

Ze'ev Maghen, After Hardship Cometh Ease: The Jews as Backdrop for Muslim Moderation (Berlin: De Gruyter, 2006), 219-220, n. 12; see also Ruth N. Sandberg, Development and Discontinuity in Jewish Law (Lanham, MD: University Press of America, 2001), 100.

36 Moses Maimonides, Mishneh Torah, Avodah Zarah, 12:10.

37 See, for example, Ma'mar b. Rāshid, al-Jāmi', in 'Abd al-Razzāq, al-Mușannaf, 11:153-156; Sunan al-Nasā̄̄ ed. Ḥasan Shalabī, 12 vols. (Beirut: Mu’assasat al-Risāla, 20o1), 8:323-324. 
The interesting feature of the hadith on hair dyeing is thus that although they expressly seek to differentiate the Muslims from the Jews, neither their prescriptions nor those of the related hair-plucking hadith actually contravene Jewish law: both traditions prohibit men from plucking their grey hairs as well as dyeing them black. In fact, then, the hadith call on Muslims to differentiate themselves not in relation to the law of the Jews, but in relation to the Jews as a group. The practice of dyeing grey hair in unnatural colours appears to be a finely calibrated statement that drew on an already known practice of dyeing hair in unnatural colours and that placed Muslims doctrinally within biblical norms but distinguished them visually from other Abrahamitic communities. This conclusion fits well with Michael Penn's observation that Christians referred to early Muslims, among other names, as "new Jews," not only for doctrinal reasons - that is, because of the Muslims' denial of the trinity — but also because the latter followed ritual practices that Jews adhered to but Christians had abandoned. ${ }^{38}$ The doctrinal and legal stances were, of course, interrelated: if, as Muhammad proclaimed, Jesus was but a prophet, he did not abolish the law, as Paul had argued, but rather was a link in its continuation, leading all the way to the prophethood of Muhammad. Juynboll, in his article, in fact entertains the potential significance of hair as a communal marker in early Islam when noting a possible parallel between hair dyeing and the Khāriji practice of shaving the head, but he does not pursue the possibility further. ${ }^{39}$

Furthermore, the case of hair dyeing permits important insights into the role of hadith and the power of hadith scholars in the development of early Islamic law. The merit of Juynboll's article on hair dyeing is that it took up, for the first time in modern scholarship, the seemingly trivial topic of personal grooming practices in hadith and pointed out that given the immense interest the topic had attracted from hadith scholars, it might yield more interesting insights than the surface suggests. Unfortunately, as noted earlier, Juynboll's investigation of the phenomenon was constrained by the Schachtian straightjacket. His focus was on identifying the second-century forgers and their motivations, and his analysis of isnāds was very limited.

The challenge to isna $\bar{d}$ analysis on the topic of hair dyeing lies in the fact that there are countless reports on the practice, formally independent but similar or identical in terms of content; see Table 9.1.

Juynboll provides a graph of the transmitters of one frequently cited report, according to which Muhammad advised, "The best dye with which you can

38 Michael Penn, Envisioning Islam: Syriac Christians and the Early Muslim World (Philadelphia: University of Pennsylvania Press, 2015), 83, 166. 
TABLE 9.1 Common hadith on hair dyeing

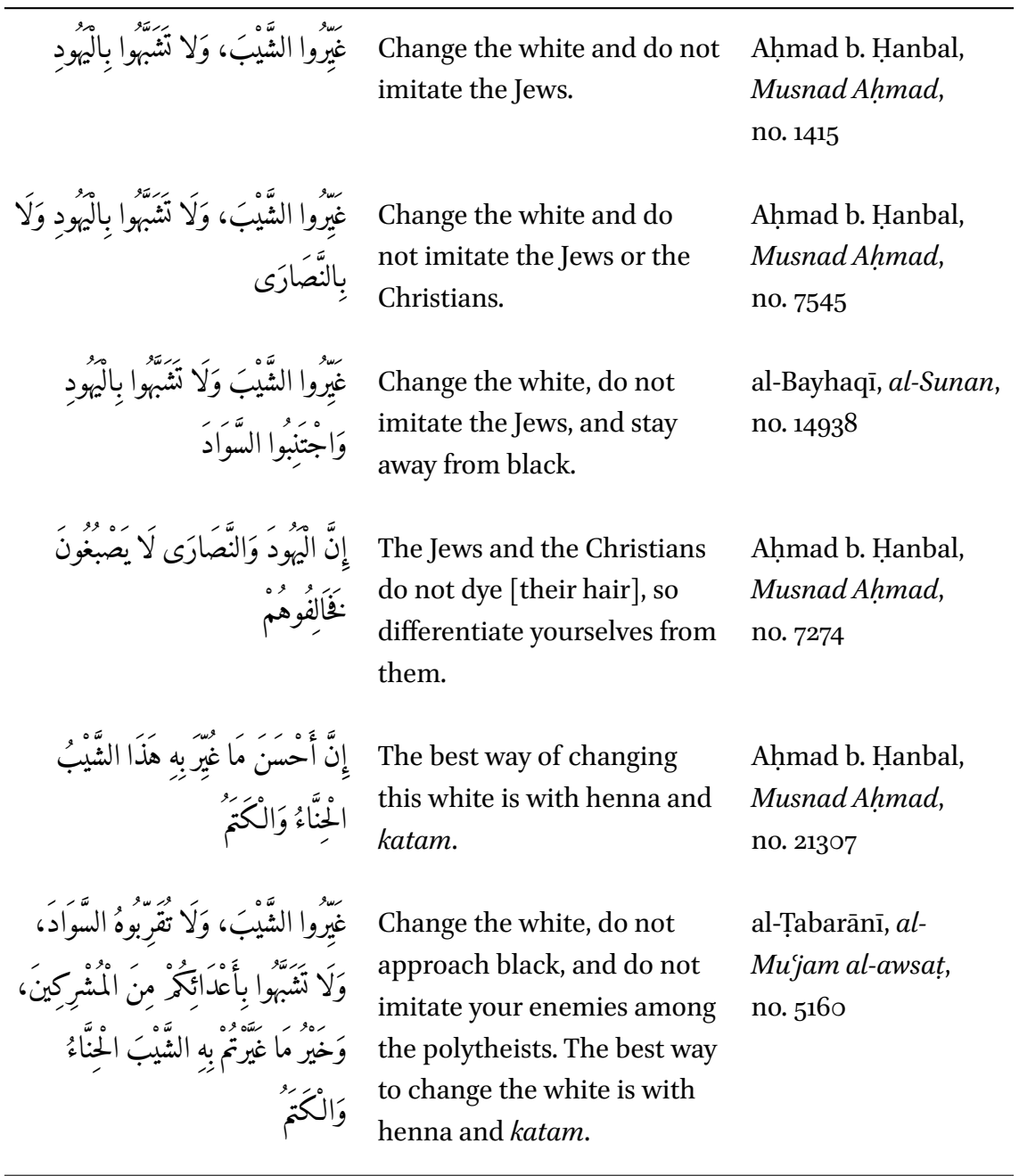

change [the colour of] your white hair is henna with katam." He establishes a certain 'Abd Allāh b. Burayda (d. 115/733) as the common link of the report, and notes that he lacks an uninterrupted isnād to the Prophet. However, complete isnāds from Ibn Burayda to Muhammad can in fact be found, even in the works that Juynboll regularly uses, as well as other isnāds that do not feature Ibn Burayda at all. ${ }^{40}$ In addition, there are other important hadith on hair dyeing

40 See Aḥmad b. Hanbal, Musnad Aḥmad, no. 21307 and footnote. 
that possess rich and varied chains of transmission. For example, Muhammad's injunction, "Change the white and do not imitate the Jews," is widely transmitted, and its chains of transmissions display partial common links in the second generation of Muslims ('Urwa b. al-Zubayr and Abū Salama b. 'Abd al-Raḥmān, both of whom died in 94/712); see Figure 9.1. ${ }^{41}$

Juynboll explains the preoccupation of certain hadith scholars with hair dyeing as a reflection of their commercial interests, noting that a considerable number of hadith scholars were known as henna sellers. ${ }^{42}$ However, the argument that such interests prompted these scholars to fabricate hadith that promoted their business is undermined by the fact that most of the scholars Juynboll names lived in the fourth and fifth centuries of the Hijra, centuries after the appearance of the hair-dyeing hadith in the hadith literature. Juynboll identifies one relatively early transmitter ('Amr b. Muhammad al-'Anqazī, d. 199/814 or 815), whose name indicates that he was a marjoram seller, and concludes that this man, too, must have dealt in henna and thus would have had a motive to further his sales by means of faked prophetic approval of his product. The claim is not impossible, but it seems rather far-fetched. More importantly, this kind of speculation distracts us from a more productive question: Why, in spite of the virtual obsession of many hadith scholars with the topic of hair dyeing, did not a single one of the Sunni or Shici schools of law come to consider hair dyeing in the colours prescribed by the Prophet a legal obligation? Consideration of this question suggests a more likely explanation than business interests for hadith scholars' enduring preoccupation with the subject.

The closest that any mainstream Sunni or Shi' $i$ jurist came to labelling reddish hair dyeing obligatory was Aḥmad b. Hanbal's proclamation, "For me, dyeing [the hair] is akin to an obligation" (al-khidāb 'indī ka-annahu fard $){ }^{43}$

41 For the chains of transmission for this hadith, see Ahmad b. Hanbal, Musnad Ahmad, nos. 1415 and 7545; al-Tirmidhī, Sunan al-Tirmidhī, ed. Bashshār 'Awwād Ma'rūf, 6 vols. (Beirut: Dār al-Gharb al-Islāmī, 1998), no. 1752; al-Bazzār, Musnad al-Bazzār, ed. Maḥfūz Zayn Allāh, 'Ādil b. Sa'd, and Șabrī al-Shāfi'ī, 18 vols. (Medina: Maktabat al-'Ulūm wa-l-Ḥikam, 1998-2009), nos. 7942 and 8681; al-Nasā'ì, Sunan al-Nasā'̀̄, no. 9291; Abū Ya'lā al-Mawșilī, Musnad Abī Yálā al-Mawșilī, ed. Ḥusayn Asad, 13 vols. (Damascus: Dār al-Ma'mūn, 1984), no. 5678; Abū Ja'far al-Ṭaḥāwī, Sharh mushkil al-āthār, ed. Shu'ayb alArna'ūt, 16 vols. (Beirut: Mu’assasat al-Risāla, 1994), no. 3678; al-Dhahabī, Tärīkh al-islām, 5:178; Sulaymān b. Aḥmad al-Ṭabarānī, al-Mújam al-awsaț, ed. Țāriq al-Ḥusaynī, 10 vols. (Cairo: Dār al-Ḥaramayn, 1995), no. 516o; Abū Saīì b. al-Árābī, Mújam Ibn al-Árrābī, ed. 'Abd al-Muhsin al-Ḥusaynī, 3 vols. (Riyadh: Dār Ibn al-Jawzī, 1997), no. 742.

42 Juynboll, "Dyeing the Hair and Beard," 73-75.

43 al-Khallāl, al-Wuqūf, 132. Aḥmad b. Huanbal's statement represents the strongest mainstream juristic support I have found for the practice, but it, too, stops short of claiming it to be obligatory. 


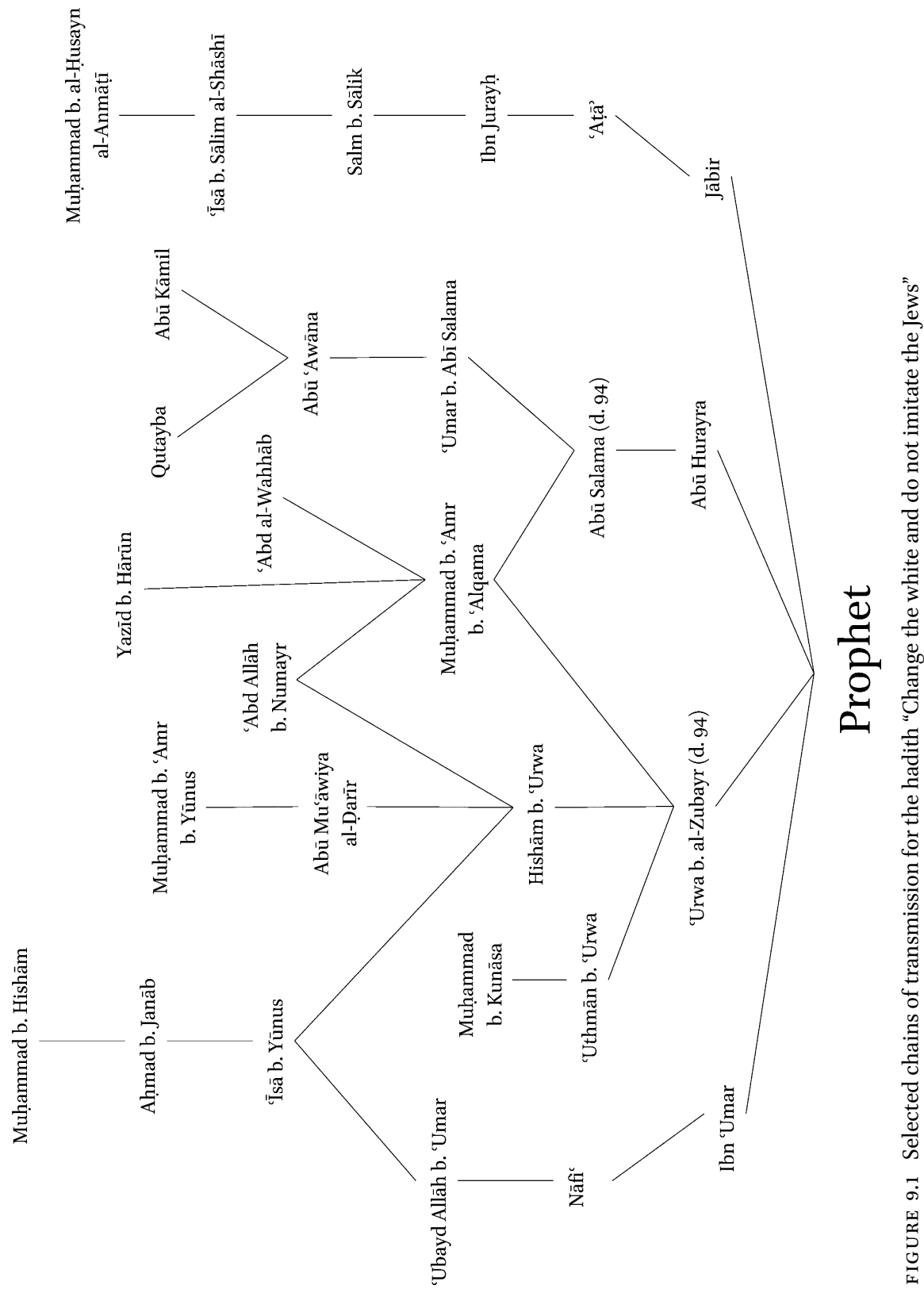


Only the late third-century Zāhirī jurist Abū Muhamammad b. Dāwūd al-Ẓāhirī (d. ca. 297/909) argued that it was actually compulsory. ${ }^{44}$ Conversely, dyeing one's grey hair black, while often discouraged, was not prohibited by the vast majority of jurists, except in cases in which a man sought to hide his age for personal gain rather than mere aesthetics, typically to deceive a prospective wife about his age. ${ }^{45}$ On a formal level this seems surprising: several hadith, classified as authentic by the hadith scholars, contain prophetic statements explicitly prescribing the dyeing of grey hair, recommending the use of henna and katam as dyeing agents, and prohibiting colouring the hair black. In addition, the strong attachment of the majority of hadith scholars as well as formative jurists such as al-Shāfi î (d. 204/820) ${ }^{46}$ to this practice indicates that there was a considerable scholarly lobby for it in the period in which the legal schools were being formed and early legal literature was being written. However, alongside the prophetic reports urging the dyeing of hair in unnatural colours there was another, contrary cluster of reports (which were often transmitted even by muhaddithün who were strongly in favour of the use of redhued dyes). According to these contrary reports, some prominent early Muslim men, including companions of Muhammad and his two grandsons Hasan and Husayn, either did not dye their grey hair at all or dyed it black ${ }^{47}$ Early jurists grappled with these two groups of reports, trying to reconcile them. Since a reconciliation was impossible if one assumed the prophetic statements in the first cluster of reports to impart obligation and prohibition in the matter of hair dyeing, the jurists had no choice but to interpret the statements to express mere preference and dislike. As a result, discussions on hair dyeing are almost nonexistent in works of Islamic law, in vivid contrast to their ubiquity in works of hadith.

The case of hair dyeing indicates that the power of early hadith scholars to influence the emerging norms of Islamic law was much more limited than Schacht and those who followed him, including Juynboll, thought. Despite the importance of hair dyeing for many major hadith scholars, despite the

\footnotetext{
44 See Ibn Qudāma, al-Mughnī, eds. Abd al-Fattāḥ al-Ḥulw and 'Abd Allāh al-Turkī, 15 vols. (Riyadh: 'Ālam al-Kutub, 1986), 1:125-126.

45 Ibn Juzayy al-Kalbī, al-Qawānīn al-fighiyya, ed. Muhammad Mawlāy (Kuwait: Wizārat al-Awqāf, 2010), 657. Some Shāfi'īs were an exception; see Muhȳi al-Dīn al-Nawawī, alMajmū'sharh al-Muhadhdhab, ed. Muḥammad Najīb al-Muṭīīi, 23 vols. (Jedda: Maktabat al-Irshād, 1992), 1:345.

46 See, for example, Ibn 'Abd al-Barr, al-Istidhkār, eds. Sālim 'Ațā and Muḥammad Mu'awwaḍ, 9 vols. (Beirut: Dār al-Kutub al-'Ilmiyya, 20oo), 8:440.

For a list of these reports, see Ibn al-Qayyim, al-Tibb al-nabawī, 279.
} 
existence of several statements attributed to Muhammad commanding the practice, and despite the absence of contradictory hadith, the reports regarding important early religious figures who contravened Muhammad's apparent commands could not be ignored, forgotten, or overruled. In contrast to Schacht's backgrowth model, in which companion reports become progressively sidelined and rendered irrelevant by prophetic hadith, this case is marked by hadith reports that indicate an early norm-dyeing the hair in unnatural colours-alongside companion reports that suggest that this norm was either abandoned relatively quickly or never seen as universally binding. While the majority of the ahl al-hadith adopted the prophetic statements as their personal guideline, the jurists concluded that the later communal practice showed that the statements in question were not legally binding on Muslims in the sense of establishing legal obligations and prohibitions. It was only the idiosyncratic later jurist Ibn Dāwūd al-Ẓāhirī who was willing to disregard all other reports in favour of upholding the hadith norms and to declare the practice of hair dyeing obligatory. ${ }^{48}$ This case thus offers an important corrective to the simplistic image of hadith scholars as being able to introduce ideas at will and have them accepted by jurists unquestioningly.

It seems, then, that men's dyeing of greying hair in unnatural colours emerged as a religious norm at an early stage to help safeguard the identity of the fledging Muslim community particularly vis-à-vis Jews in an environment in which the two communities often shared broadly similar norms (in this case, the norms against plucking greying hairs or dyeing them in their original colour). Over time, however, as the Muslims' communal identity became increasingly consolidated in the context of an established territorial empire, the practice was largely abandoned. The anecdote quoted at the beginning of this paper, involving a man who did not dye his hair because he was reportedly ashamed, is evocative: it suggests that in the cosmopolitan and securely Muslim milieu of mid-third-century Baghdad, artificially red hair had become an aesthetic embarrassment. In this later cultural environment, then, dyeing one's hair took on a countercultural significance as a token of group identity for the ahl al-hadith, who saw themselves as rescuing a dying sunna from oblivion. ${ }^{49}$

Meanwhile, the practical significance of red hair was superseded by new forms of distinction. By the third/ninth century, confessional differentiation

48 It is, therefore, no coincidence that the most prominent living Zāhirī scholar, the Saudi Abū 'Abd al-Raḥmān Ibn 'Aqīl al-Z̄āhirī (born 1942), dyes his beard a reddish colour.

49 It is probably in this context that selling henna became a signature occupation of hadith scholars (who often made their living as traders, anyway). 
was enforced through official mechanisms such as administrative and tax status and, in urban areas, the so-called ghiyār system, which forbade nonMuslims to dress like Muslims. ${ }^{50}$ According to the so-called "Stipulations of 'Umar" (dating from anywhere between the reign of 'Umar and the third/ninth century), non-Muslims undertook "not to imitate Muslims" (lā natashabbah bi-l-muslimin) in terms of their headdress, footwear, or the manner of parting their hair. Therefore, as Muslims went from minority to majority, the burden of manifesting communal distinctions shifted from Muslims to non-Muslims, and Muslims could afford to dispense with their historical identity markers. By contrast, Maimonides, writing in the Egyptian diaspora, could not do so and in fact felt obliged to prescribe a harsh punishment for failure to uphold the Jewish community's boundaries: he ruled that any man caught dyeing as much as a single hair black deserved whipping. ${ }^{51}$

In sum, the hadith on hair dyeing, together with an array of sources from genres as varied as historical chronicles, biographies, poetry, an apocryphal gospel, and Halakha, indicate that significant numbers of early Muslim men dyed their hair and beards in reddish hues, and that they did so in order to distinguish themselves visually from other religious communities while remaining within the bounds of biblical law. This practice of embodied boundary-making supports the hypothesis that early Muslims saw themselves as an Abrahamitic reform movement that was not part of either Christianity or Judaism but separate from both. The Qurān, too, talks about Judaism and Christianity on two distinct planes: a doctrinal one, on which dogmas such as the Christian trinity and the Jewish non-recognition of Jesus can be criticised even as communalities in belief and ethics are stressed; and a communal one, on which issues of trustworthiness and good will are discussed. The hadith on hair dyeing render these two planes tangible, since they both affirm the continued relevance of biblical law yet prescribe a visible communal boundary. The divergent unfolding of the discourse on hair dyeing in Jewish and Islamic law offers a case study of the same motives being refracted through very different religious and historical concerns to produce laws that are intimately related yet incommensurable.

$5^{\circ} \quad$ Luke Yarbrough, "Origins of the ghiyār," Journal of the American Oriental Society 134, no. 1 (2014): 113-121.

51 Maimonides, Mishneh Torah, Avodah Zarah, 12:10. 


\section{Bibliography}

Abū Ya'lā al-Mawșilī. Musnad Abı̄ Ya lā al-Mawșilī. Edited by Ḥusayn Asad. 13 vols. Damascus: Dār al-Ma'mūn, 1984.

Abū Yūsuf. al-Āthār. Edited by Abū al-Wafā’ al-Afghānī. Hyderabad: Dār Ihyā̄a al-Ma'ārif al-'Uthmāniyya, 1355/1936.

Aḥmad b. Hanbal. Masāill al-imām Aḥmad b. Hanbal, riwāya Ibn Ab̄̄ al-Faḍl Șāliḥ. Edited by Faḍl al-Raḥmān Dīn Muḥammad. 3 vols. Delhi: al-Dār al-'Ilmiyya, 1988.

Aḥmad b. Ḥanbal. Musnad al-imām Aḥmad b. Hanbal. Edited by Shu'ayb al-Arna’ūṭ, 'Ādil Murshid et al. 45 vols. Beirut: Mu’assasat al-Risāla, 1993-2001.

al-'Aynī, Badr al-Dīn. 'Umdat al-qārī. 25 vols. Cairo: al-Maṭba'a al-Munīriyya, 1929. al-Bājūrī, Ibrāhīm. al-Mawāhib al-laduniyya. In: Muhammad b. 'Īsā al-Tirmidhī, alShamāil al-muḥammadiyya, edited by Muḥammad 'Awwāma. N.p.: n.p., 2001.

al-Bayhaqī, Abū Bakr. al-Sunan al-kubrā. Edited by 'Abd Allāh al-Turkī. 24 vols. Cairo: Markaz Hijr, 2011.

al-Bazzār, Abū Bakr Aḥmad b. 'Amr. Musnad al-Bazzār. Edited by Maḥfūẓ Zayn Allāh, 'Ādil b. Sa'd, and Șabrī al-Shāfi'̄. 18 vols. Medina: Maktabat al-'Ulūm wa-l-Ḥikam, 1998-2009.

al-Dhahabī, Shams al-Dīn. Tārīkh al-islām. Edited by Bashshār 'Awwād Ma'rūf. 15 vols. Beirut: Dār al-Gharb al-Islāmī, 2003.

Horn, Cornelia. "Apocalyptic Ecclesiology in Response to Early Islam: The Evidence of the Arabic Apocryphal Gospel of John." Paper presented at the meeting of the American Oriental Society, Boston, 17 March 2012.

Horn, Cornelia. "Editing a Witness to Early Interactions Between Christian Literature and the Qurān: status quaestionis and Relevance of the Arabic Apocryphal Gospel of John." Parole de l'Orient 37 (2012): 1-16.

Horn, Cornelia. "Syriac and Arabic Perspectives on Structural and Motif Parallels Regarding Jesus' Childhood in Christian Apocrypha and Early Islamic Literature: The 'Book of Mary,' the Arabic Apocryphal Gospel of John and the Qur'ān." Apocrypha 19 (2008): 267-291.

Hoyland, Robert. Seeing Islam as Others Saw It. Princeton, NJ: Darwin Press, 1997.

Huici Miranda, Ambrosio. "Ibn Ḥayyān." In Encyclopaedia of Islam, 2nd edition, vol. 3: H-Iram. Edited by P.J. Bearman, Th. Bianquis, C.E. Bosworth, E. van Donzel, and W.P. Heinrichs, 789-79o. Leiden: Brill, 1971.

Ibn 'Abd al-Barr. al-Istidhkār. Edited by Sālim 'Ațā and Muḥammad Mu'awwaḍ. 9 vols.

Beirut: Dār al-Kutub al-'Ilmiyya, 2000.

Ibn 'Abd al-Barr. al-Tamhìd li-mā fi al-Muwațța' min al-ma'ānī wa-l-asānīd. Edited by Muṣțafā al-'Alawī and Muhammad al-Bakrī. 24 vols. Rabat: Wizārat al-Awqāf, 19741992.

Ibn Abī Shayba. al-Mușannaf. Edited by Kamāl al-Ḥūt. 7 vols. Riyadh: Maktabat alRushd, 1409/1988 or 1989 . 
Ibn al-Árābī, Abū Sa'̄ìd. Múcjam Ibn al-A'rābī. Edited by 'Abd al-Muḥsin al-Husaynī. 3 vols. Riyadh: Dār Ibn al-Jawz̄̄̄, 1997.

Ibn Durayd. Jamharat al-lugha. Edited by Ramzī Munīr Ba'lbakī. 3 vols. Beirut: Dār al'Ilm li-l-Malāyīn, 1987-1988.

Ibn 'Idhārī, Muhammad. Kitāb al-Bayān al-mughribfíakhbār al-Andalus wa-l-Maghrib. Edited by George Colin, Evariste Lévi-Provençal, and Iḥān 'Abbās. 4 vols. Beirut: Dār al-Thaqāfa, 1967 .

Ibn Juzayy al-Kalbī. al-Qawānīn al-fiqhiyya. Edited by Muḥammad Mawlāy. Kuwait: Wizārat al-Awqāf, 2010.

Ibn Qayyim al-Jawziyya. al-Tibb al-nabawī. Beirut: Dār al-Hilāl, 1983 .

Ibn Qudāma. al-Mughnī. Edited by Abd al-Fattāḥ al-Ḥulw and 'Abd Allāh al-Turkī. 15 vols. Riyadh: 'Ālam al-Kutub, 1986.

Iohannis evangelium apocryphum Arabice. Edited by Giovanni Galbiati. Milan: Arnoldo Mondadori Editore, 1957.

Juynboll, Gautier H.A. "Dyeing the Hair and Beard in Early Islam: A Hadìth-analytical Study." Arabica 33, no. 1 (1986): 49-75.

al-Khallāl, Abū Bakr. al-Wuqūf wa-l-tarajjul min al-Jāmic li-masāil Aḥmad b. Hanbal. Edited by Sayyid Kasrawī Hasan. Beirut: Dār al-Kutub al-'Ilmiyya, 1994.

Kister, Meir Jacob. “'Do not assimilate yourselves ...': lā tashabbahū.” Jerusalem Studies in Arabic and Islam 12 (1989): 321-371.

Maghen, Ze'ev. After Hardship Cometh Ease: The Jews as Backdrop for Muslim Moderation. Berlin: De Gruyter, 2006.

Ma'mar b. Rāshid. al-Jāmic. Vols. 11 and 12 of 'Abd al-Razzāq al-Ṣanānī, al-Muṣannaf. Edited by Ḥabīb al-Raḥmān al-A'ẓamī. Simlak: al-Majlis al-'Ilmī, 1970-1972.

al-Maqqarī, Aḥmad b. Muḥammad. Naf̣̣ al-țīb. Edited by Iḥsān 'Abbās. 8 vols. Beirut: Dār Șādir, 1968.

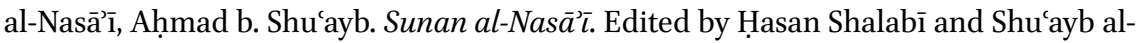
Arna'ūṭ. 12 vols. Beirut: Mu'assasat al-Risāla, 2001.

al-Nawawī, Muḥȳi al-Dīn. al-Majmū̌ sharh al-Muhadhdhab. Edited by Muḥammad Najīb al-Muṭịīi 23 vols. Jedda: Maktabat al-Irshād, 1992.

Patel, Youshaa. "Muslim Distinction: Imitation and the Anxiety of Jewish, Christian, and Other Influences." PhD diss., Duke University, 2012.

Penn, Michael. Envisioning Islam: Syriac Christians and the Early Muslim World. Philadelphia: University of Pennsylvania Press, 2015.

al-Quḍā̄ì̄, Abū 'Abd Allāh. Musnad al-Shihāb. Edited by Ḥamdī al-Salafī. 2 vols. Beirut: Mu'assasat al-Risāla, 1986.

Sandberg, Ruth N. Development and Discontinuity in Jewish Law. Lanham, MD: University Press of America, 2001.

Schöller, Marco. “Opposition to Muhammad." In Encyclopaedia of the Qur'ān, edited by Jane Dammen McAuliffe. Accessed 3 February 2018. https://referenceworks.brillon 
line.com/entries/encyclopaedia-of-the-quran/opposition-to-muhammad-EQCOM _oo139?s.num=o\&s.f.s2_parent=s.f.book.encyclopaedia-of-the-quran\&s.q=Opposi tion+to+Mu\%E1\%B8\%A5ammad.

Schönig, Hannelore. Schminken, Düfte und Räucherwerk der Jemenitinnen: Lexikon der Substanzen, Utensilien und Techniken. Beirut: Orient-Institut, 2002.

Sherrow, Victoria. For Appearance' Sake: The Historical Encyclopedia of Good Looks, Beauty, and Grooming. Phoenix: Oryx Press, 2001.

Stetkevych, Suzanne Pinckney. The Mute Immortals Speak: Pre-Islamic Poetry and the Poetics of Ritual. Ithaca, NY: Cornell University Press, 1993.

Stetkevych, Suzanne Pinckney. The Poetics of Islamic Legitimacy: Myth, Gender, and Ceremony in the Classical Arabic Ode. Bloomington: Indiana University Press, 2002. al-Ṭabarānī, Sulaymān b. Aḥmad. al-Mújam al-awsaț. Edited by Ṭāiq al-Ḥusaynī. 10 vols. Cairo: Dār al-Haramayn, 1995.

al-Ṭabarī, Muhammad b. Jarīr. Tahdhīb al-āthār: al-Juz' al-mafqūd. Edited by 'Alī Riḍā. Damascus: Dār al-Ma’mūn, 1995.

al-Ṭahāwī, Abū Jađfar. Sharh mushkil al-āthār. Edited by Shu'ayb al-Arna’ūṭ. 16 vols. Beirut: Mu’assasat al-Risāla, 1994.

al-Tirmidhī, Muḥammad b. ‘̄̄sā. al-Shamā'il al-muḥammadiyya. Edited by Muḥammad 'Awwāma. N.p.: n.p., 2001.

al-Tirmidhī, Muḥammad b. 'Īsā. Sunan al-Tirmidhī. Edited by Bashshār 'Awwād Ma'rūf. 6 vols. Beirut: Dār al-Gharb al-Islāmī, 1998.

Yarbrough, Luke. "Origins of the ghiyār." Journal of the American Oriental Society 134, no. 1 (2014): 113-121. 